\title{
Pre-emption of the substratum and the maintenance of spatial pattern on a rocky shore in the northwest Mediterranean
}

\author{
Lisandro Benedetti-Cecchi*, Massimo Menconi, Francesco Cinelli \\ Dipartimento di Scienze dell'Uomo e dell'Ambiente via A. Volta 6, I-56126 Pisa, Italy
}

\begin{abstract}
This study examined the effects of removing dominant organisms from different types of patches at different heights on a rocky shore in the northwest Mediterranean. It was proposed that preemption of the substratum was a key process in maintaining differences among patches low on the shore, while physical factors were potentially more important at higher tidal levels. In a first experiment we removed barnacles and turf-forming/encrusting algae from areas of substratum just above and below the upper and lower limits of distribution of the red alga, Rissoella verruculosa, respectively. The experimental plots were either completely cleared, partially cleared (organisms were removed from $50 \%$ of the substratum) or left undisturbed (controls). Treatments were replicated in 4 sites (stretches of coastline of 8 to $10 \mathrm{~m}$ ) above, and 4 sites below, the limits of distribution of Rissoella. This experiment was initiated twice, in July 1994 and January 1995. In a second experiment we manipulated the coverage of Rissoella in correspondence to its upper and lower margins of distribution. The design of this experiment was similar to the previous one. In this case the experimental units consisted of plots where Rissoella was either completely removed or where only the erect fronds were removed while the encrusting base was left in place, and controls. This experiment was done only once (from July 1994 to July 1996). The results of the 2 experiments indicated that when dominant organisms were cleared from the substratum, other species could either extend their vertical range of distribution occupying areas where they did not occur before, as in the case of Rissoella, or change their local abundance as in the case of encrusting algae, Rivularia spp., limpets and the recruits of Chthamalus stellatus. With the exception of Rivularia, clearing areas of substratum had similar effects at different heights on the shore. The model that pre-emption of the substratum maintained differences among patches low, but not high on the shore, was not supported by the experimental results. These indicated that pre-emption of the substratum operated independently from other physical and/or biological processes in influencing vertical patterns of distribution. The large variability among sites documented in this study suggested that models of the distribution of plants and animals should also consider horizontal scales of variation
\end{abstract}

KEY WORDS: Algae - Boundaries Invertebrates - Natural variability Patchiness - Rocky shores S Spatial heterogeneity

\section{INTRODUCTION}

Understanding ecological heterogeneity is one of the ultimate goals of the science of ecology. In general, physical and biological processes operate interactively to generate spatial and temporal variability in natural populations and assemblages (Underwood 1985. Menge \& Sutherland 1987, Danielson 1991). Natural

•E-mail: bencecc@discat.unipi.it systems are often described as mosaics of patches, where a patch is a discrete area of the habitat which differs in its physical and/or biological attributes from nearby areas (Pickett \& White 1985, Kotliar \& Wiens 1990). Although the term 'patch' has been used in a variety of contexts and a formal, universally accepted definition is still lacking, the concept makes explicit reference to spatial patterning and provides a useful framework for the study of heterogeneity (Wiens et al. 1993). In addition, patchiness may occur at a variety of 
spatial scales. At the scale of the landscape, spatial mosaics have provided a focus for studies on the effects of habitat fragmentation and its implications for environmental conservation (Turner et al. 1995, Bender et al. 1998). At local, within habitat scales, patchiness has provided a framework for the analysis of a number of basic ecological processes, including recruitment (Grosberg 1982, Gaines et al. 1985), dispersion and movement (Stamps et al. 1987, Diffendorfer et al. 1995), foraging behaviour (Chapman \& Underwood 1992) and trophic and non trophic interactions (Dayton 1992). Irrespective of scale, a better understanding of ecological heterogeneity requires knowledge of the processes that generate and maintain discontinuities among patches. It has been argued that experimental investigations at small spatial scales may be useful to predict large-scale processes that are less amenable to formal experimentation (Wiens et al. 1993).

Early studies on rocky shores described the vertical distribution of organisms in response to the major environmental gradient of emersion, and how these patterns changed with wave action (Stephenson \& Stephenson 1949, Southward 1958, Lewis 1964). Vertical patterns were initially thought to reflect the physiological tolerance of organisms to physical factors. Since the mid 1960 s, evidence has accumulated indicating the direct setting of upper limits by physical factors (Connell 1972, Schonbeck \& Norton 1978, Lubchenco 1980, Norton 1985), and the establishment of lower limits by biological processes such as predation (Paine 1974), grazing (Lubchenco 1980, Moreno \& Jaramillo 1983) and competition, the latter often in the form of pre-emption of the substratum (Connell 1961, Lubchenco 1980, Schonbeck \& Norton 1980, Hawkins \& Hartnoll 1985). Other studies, however, indicated that biological interactions, or the interactive effects of physical and biological factors, may provide alternative explanations for the location of the upper boundaries of distribution of some intertidal and subtidal species (Underwood 1980, Sousa et al. 1981, Underwood \& Jernakoff 1981, Lubchenco 1982, Cubit 1984, Santelices \& Ojeda 1984, Graham 1997). A problem in deriving general conclusions from these studies is that only in a few cases have the processes influencing the upper and lower boundaries of distribution of a particular species been investigated simultaneously (e.g. Schonbeck \& Norton 1978,1980 ). This approach would provide additional insights into the roles of physical and biological factors and their interactions in generating spatial patterns on rocky shores.

In the Mediterranean, mid-shore assemblages are dominated by the red alga Rissoella verruculosa (Bertolini) J. Agardh (hereafter Rissoella) which forms discrete patches with distinct upper and lower limits of distribution (Menconi et al. in press). Other algae, encrusting cyanobacteria (Rivularia spp.) and barna- cles, primarily Chthamalus stellatus (Poli), are also common at different levels on the shore. Barnacles are the most abundant organisms above Rissoella, although they are also common within patches of this alga. Below the lower limit of distribution of Rissoella, patches of algal turfs (filamentous algae and articulated corallines), encrusting corallines and the brown crust Ralfsia verrucosa (Areshough) J. Agardh, are dominant (Benedetti-Cecchi \& Cinelli 1993, 1994, 1997). These patterns, however, are very variable. $R$ issoella is not always present on the shore, it may occur at different levels on different shores, and sometimes it occurs in mixed assemblages with filamentous and encrusting algae. Temporal dynamics may also differ from patch to patch and from one shore to another (Menconi et al. 1999, Benedetti-Cecchi unpubl. data).

This study consisted of the experimental removal of dominant organisms at the borders of 3 different types of patches (barnacles at high levels on the shore, Rissoella at mid levels and turf-forming/encrusting algae at low levels), to test for the reciprocal interactions among these dominants as well as for their effects on less abundant species. These experiments tested the general model that pre-emption of the substratum was a key process in maintaining differences among patches low on the shore, while physical factors were potentially more important at higher tidal levels. To examine the generality of the processes investigated, we also tested whether the direction and magnitude of interactions were consistent from one area of the shore to another and through time. This was achieved by replicating the experiments in different sites at different starting dates.

\section{MATERIALS AND METHODS}

Study areas. This study was carried out from July 1994 to January 1997 on the exposed rocky shore of Calafuria $\left(43^{\circ} 28^{\prime} \mathrm{N}, 10^{\circ} 20^{\prime} \mathrm{E}\right)$, south of Livorno, Italy. Experimental areas were established on sandstone platforms distributed along about $1 \mathrm{~km}$ of the coast. Several patches of Rissoella were located at mid levels on the shore, between 0.1 and $0.4 \mathrm{~m}$ above the mean low water level.

Removal of barnacles and turf-forming/encrusting algae. In a first experiment we removed barnacles and turf-forming/encrusting algae from areas of substratum just beyond the upper and lower limits of distribution of Rissoella, respectively. This experiment tested primarily for the effects of intensity of disturbance (control vs half removal vs total removal plots; hereafter referred to as 'disturbance'), position with respect to the margins of distribution of Rissoella (upper vs lower margin; hereafter referred to as 'margin'), site ( 4 replicate sites) and date of clearing (2 starting dates), on the vertical distribution of Rissoella. 
In addition, we also tested for the effects of these factors on the recruitment of barnacles, on the coverage of the encrusting cyanobacteria Rivularia spp., and on the density of limpets. The prediction was that the effects of removing turf-forming/encrusting algae low on the shore were larger than those of removing barnacles at higher levels, where severe physical conditions should limit the establishment of organisms. In July 1994, 16 sites dominated by Rissoella were selected randomly from a larger number of available sites, each one representing a stretch of coastline of 8 to $10 \mathrm{~m}$. These sites were randomly assigned to each of the 2 starting dates of the experiment, July 1994 and January 1995, with 8 sites per date. These dates were chosen as representative of 2 different stages of the life-cycle of Rissoella (but see below). In fact, Rissoella is present on the shore mainly as a crust during the summer, while it has the form of a fleshy, frondose alga, from autumn to late spring (Benedetti-Cecchi \& Cinelli 1993, 1997). We tested whether the capabilities of Rissoella to colonize new patches of substratum changed through time and in relation to the morphology of the alga. We also tested for temporal changes in the establishment of the other organisms. At each date, treatments were established in areas occupied by barnacles just above the upper limit of distribution of Rissoella in 4 of the 8 sites (randomly chosen), and in areas occupied by turf-forming/encrusting algae at the lower limit of distribution of Rissoella in the remaining sites. In each site, 3 replicate plots of $7 \times 12$ $\mathrm{cm}$ of each of the following treatments were established: (1) total removal of organisms, (2) removal of organisms from $50 \%$ of the surface of the plot, and (3) untouched controls. The half removal treatment was made by subdividing the surface of the plot in 8 sub-quadrats of equal size, and clearing 4 of them chosen at random. This treatment simulated a disturbance event of lower intensity than that necessary to clear a whole quadrat. It was included to test for the effects of space when provided in the form of several small quadrats, as opposed to a single relatively large quadrat. The prediction was that pre-emption of space was more effective in half removal plots (presumably edge effects were more important there) than in total removal plots.

The experimental units were cleared using a hammer and chisel and were marked at the 4 corners with small pieces of epoxy-putty (Subcoat S, Veneziani) for subsequent location.

Removal of Rissoella. In a second experiment, we manipulated the coverage of Rissoella in correspondence to its upper and lower margins of distribution. We tested for the effects of Rissoella (control vs bases vs total removal), margin (2 levels: upper vs lower margin) and site ( 4 replicate sites), on the distribution of fila- mentous and encrusting algae, barnacles and limpets. The predicted outcome was a larger effect of Rissoella low on the shore. In July 1994, 8 sites dominated by Rissoella were selected as described above and 9 plots of $7 \times 12 \mathrm{~cm}$ were marked in each site. These plots were located in correspondence to the upper limit of distribution of Rissoella in 4 sites chosen at random, and in correspondence to the lower limit in the remaining sites. Three replicates of the following treatments were established in each site: (1) removal of the erect fronds of Rissoella, (2) removal of both erect fronds and the encrusting base, and (3) untouched controls. These treatments were included to test which portion of the thallus of Rissoella, if any, affected the distribution of other organisms on the shore. Erect fronds and bases were removed using a razor blade; care was taken not to damage other organisms during the removal. The experiment was terminated in July 1996.

Collection and analysis of data. In both experiments, the percentage cover of sessile organisms was estimated in an area of $5 \times 10 \mathrm{~cm}$ in the centre of each plot using a rubber frame with a grid of fifty $8 \times 8 \mathrm{~mm}$ holes. The abundance of limpets was estimated by counting the number of individuals present in whole plots; only animals larger than 6 to $8 \mathrm{~mm}$ were considered. These organisms were sampled almost every 2 to 3 mo for 2 yr. Sampling was not possible in November 1995 and October 1996 due to rough weather. Recruitment of barnacles was also estimated on 1 occasion. Barnacles recruit mostly during the summer on these shores (Benedetti-Cecchi et al. unpubl. data). In July 1995, plots of both experiments were photographed with a Nikonos 5 camera and close-up lens. Recruits (spats and recently metamorphosed barnacles) were counted by examining the slides under a dissecting microscope. Only the scraped sub-quadrats were monitored in the half removal treatment. To standardise the sampling surface, similar sub-quadrats were sampled in control and total removal plots.

Data were analysed using analysis of variance (ANOVA). In the first experiment, 'Disturbance', 'Margin' and 'Date' were fixed, orthogonal factors, and 'Site' was random and nested in the interaction Margin $\times$ Date. For the analysis on Rissoella, 'Date' was treated as a fixed factor because different dates corresponded to 2 distinct morphologies of the alga (encrusting bases vs erect fronds). For the other organisms, 'Date' was fixed because each date corresponded to a particular season (summer vs winter). However, it is worth noting that this design confounded differences in morphology of Rissoella with temporal changes. In addition, the experiment should have been repeated more than once for each period characterized by a particular morphology, to avoid problems of pseudoreplication in time. Replicated dates within periods were also neces- 


\section{Upper margin A Rissoella verruculosa Lower margin}
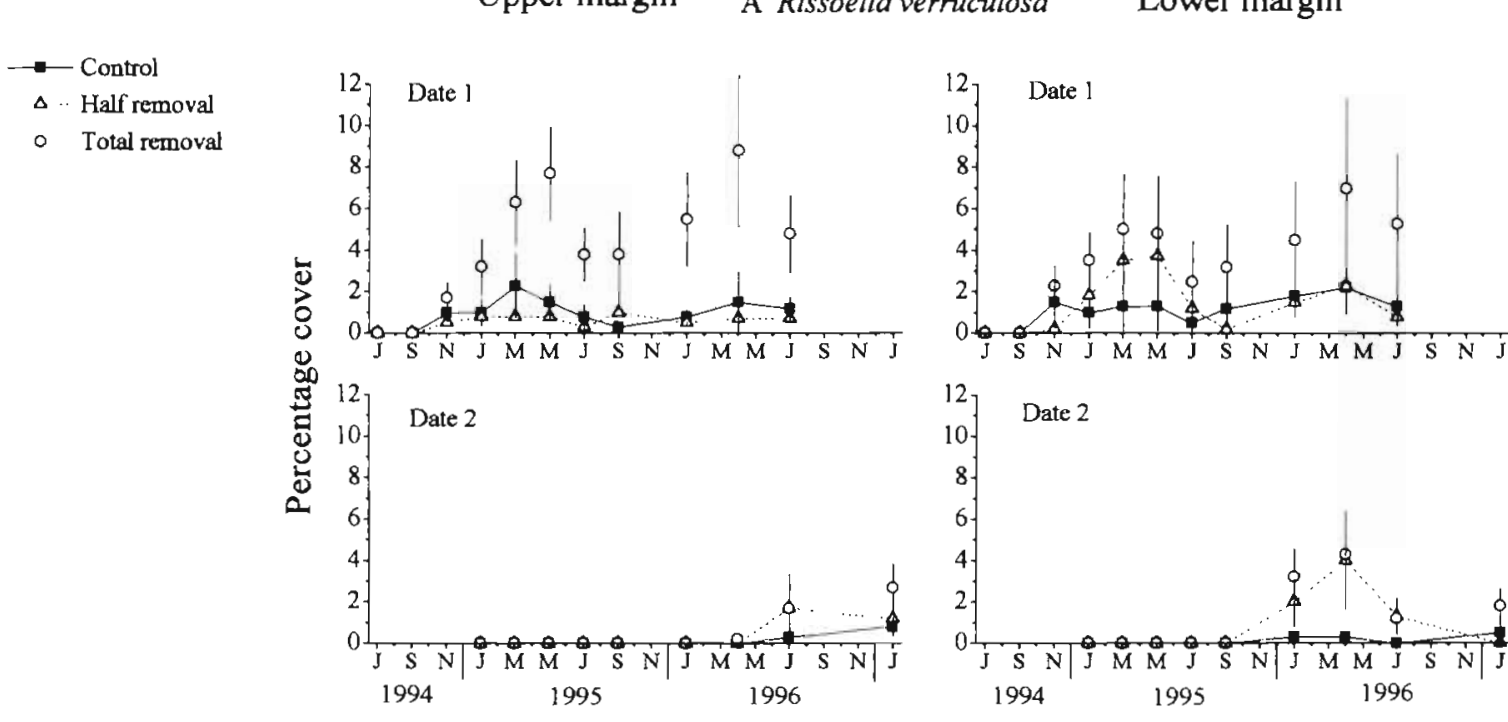

Fig. 1. Rissoella verruculosa and Rivularia spp. Effects of removing barnacles high on the shore and turf-forming/ encrusting algae low on the shore on (A) Rissoella and (B) Rivularia. Data are mean percentage covers $( \pm \mathrm{SE}, \mathrm{n}=$ 12) from 3 replicate plots pooled across 4 replicate sites at each margin and starting date

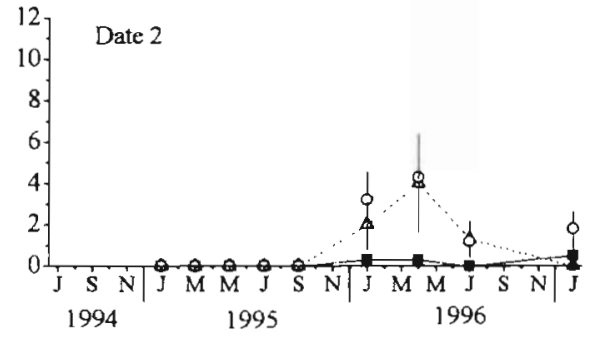

B Rivularia spp.
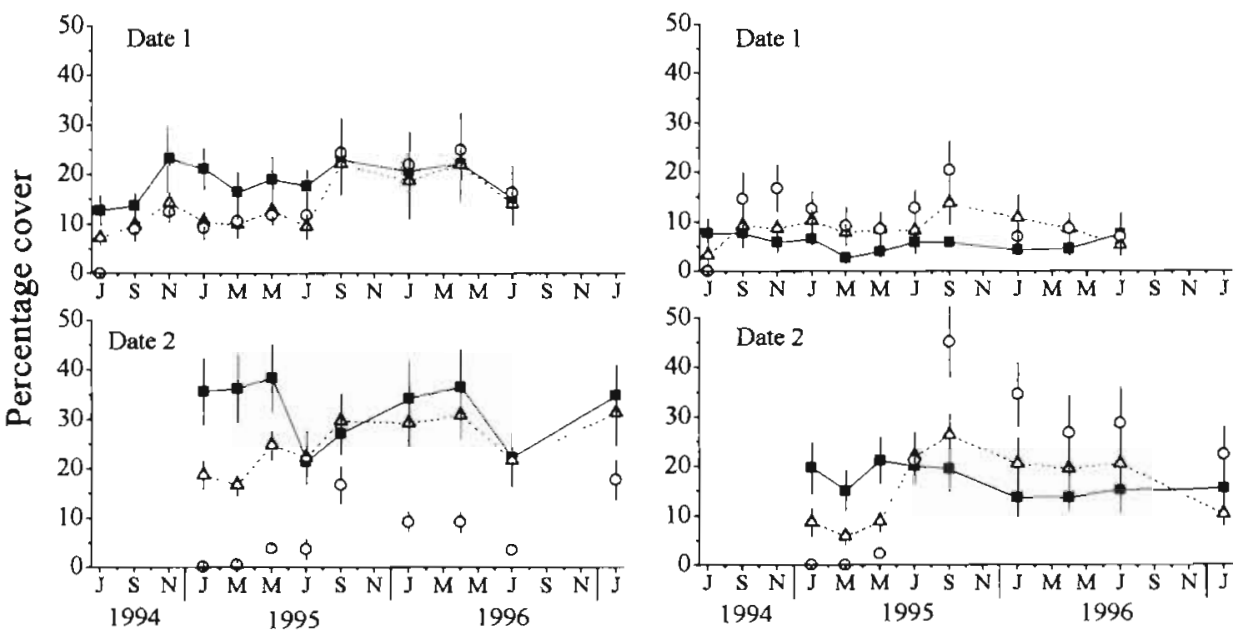

to the unmanipulated ones. Colonization of Rivularia was more intense at the lower margin, where scraped plots supported a larger cover of cyanobacteria than the other treatments during most of the experiment (Fig. 1B). These patterns resulted in a significant Disturbance $\times$ Margin $\times$ Date interaction (Table 1 and SNK tests). There were also significant differences in the percentage cover of Rivularia from site to site (Table 1).

Removing barnacles above and turf-forming/encrusting algae below Rissoella increased the local abundance of limpets (Fig. 2). In general, plots that were completely scraped supported a larger density of these herbivores than the other treatments. However, despite a significant effect of Disturbance (Table 1), the SNK test could not discriminate which means differed. Limpets were significantly more abundant at low than high levels on the shore and significant differences also occurred among sites (Fig. 2, Table 1).

Removing sessile organisms beyond the upper and lower limits of distribution of Rissoella had no effects on recruitment of barnacles (Fig. 3). Although there were significantly more recruits of Chthamalus spp. at high than low levels on the shore, the intensity of recruitment was very variable and changed significantly from site to site (Table 1).

\section{Removal of Rissoella}

The filamentous algae were significantly more abundant at the lower margin of distribution of Rissoella but were unaffected by the removal of this alga (Fig. 4A. 


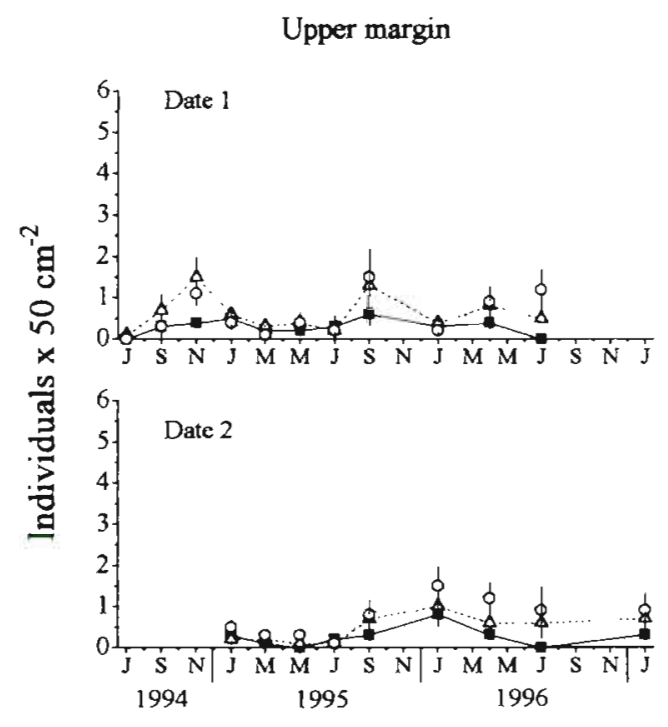

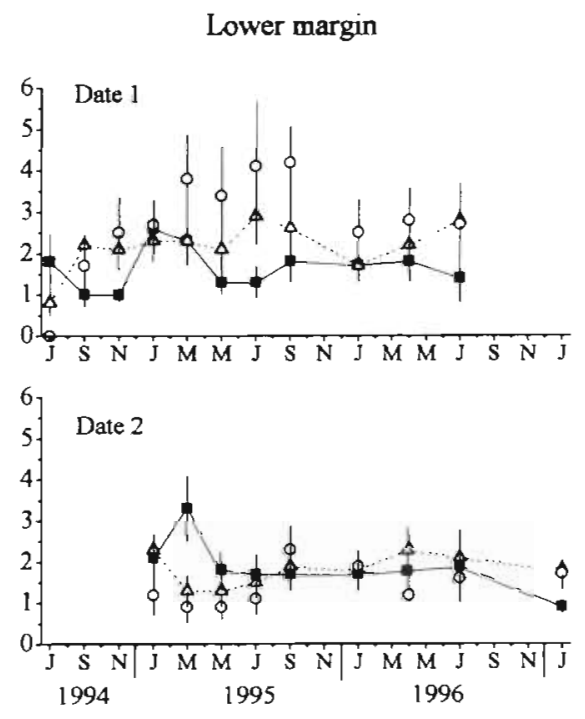

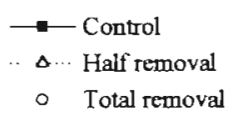

Fig. 2. Patella spp. Effects of removing barnacles high on the shore and turf-forming/ encrusting algae low on the shore on Patella. Data are mean densities ( $\pm \mathrm{SE}, \mathrm{n}=12$ ) from 3 replicate plots pooled across 4 replicate sites at each margin and starting date
Table 2). In contrast, Rissoella had significant effects on both the encrusting coralline algae and Rivularia (Fig. 4B,C, Table 2). There were more encrusting coralline algae in control plots than in plots where either the fronds or the fronds plus the bases of Rissoella were removed (Fig. 4B). Although there was no significant effect of Rissoella in the analysis of variance $\left(F_{2,12}=3.19, \mathrm{p}=0.07\right.$, see Table 2$)$, the SNK test revealed a significant larger cover of encrusting coralline algae in control plots than in the other treatments, which did not differ significantly. The abundance of these algae also differed significantly from site to site (Table 2). In contrast, Rissoella had significant negative effects on Rivularia, both at the upper and lower margin (Fig. 4C, Table 2). The SNK test indicated that the percentage cover of cyanobacteria was significantly larger in plots where both the fronds and the bases of Rissoella were removed than in plots where only the fronds were eradicated. These plots, in turn, supported significantly more cyanobacteria than the controls.
The removal of Rissoella had no effects on the percentage cover of barnacles, nor on the density of limpets. For each of these animals, abundances at the upper margin of Rissoella were similar to those observed at the lower margin (Fig. 5). There were highly significant differences among sites for both these organisms (Table 3). Despite the lack of long term effects of Rissoella on the percentage cover of barnacles, the establishment of these animals was strongly influenced by the presence of the alga (Fig. 6). The removal of both the fronds and the bases of Rissoella significantly enhanced recruitment in comparison to the other treatments (Table 3 and SNK test).

\section{DISCUSSION}

This study indicated that when dominant organisms were removed from the substratum, other species could either extend their vertical range of distribution
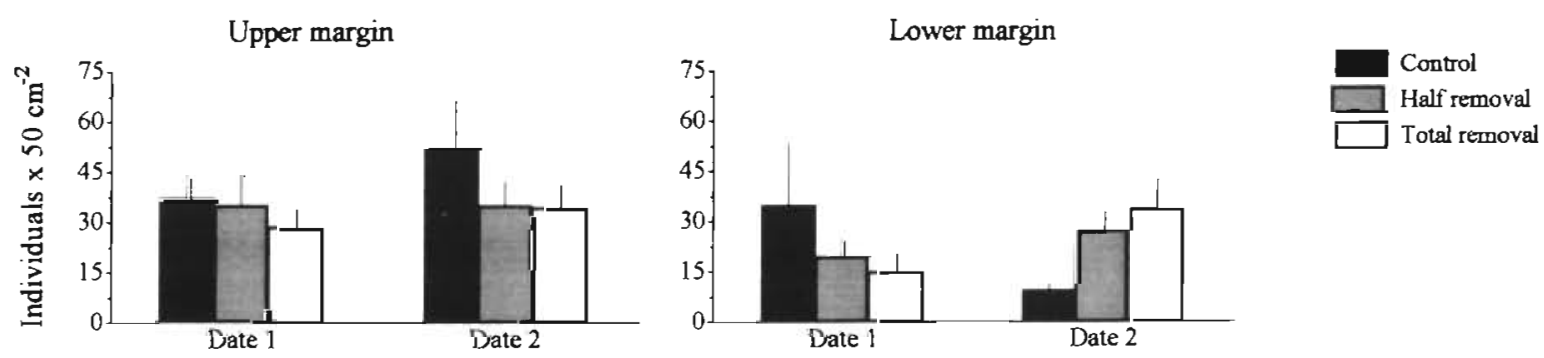

Fig. 3. Chthamalus spp. Effects of removing barnacles high on the shore and turf-forming /encrusting algae low on the shore on recruitment of Chthamalus in July 1995. Data are mean numbers of recruits $( \pm S E, n=12$ ) from 3 replicate plots pooled across 4 replicate sites at each margin 


\section{Upper margin A Filamentous algae Lower margin}

- Control
$\ldots \Delta$ Fronds removed
- Fronds and bases removed
Fig. 4. Effects of removing Rissoella at its upper and lower margins of distribution on (A) filamentous algae, (B) encrusting algae, and (C) Rivularia. Data are mean percentage covers $( \pm \mathrm{SE}, \mathrm{n}$ $=12$ ) from 3 replicate plots pooled across 4 replicate sites at each margin
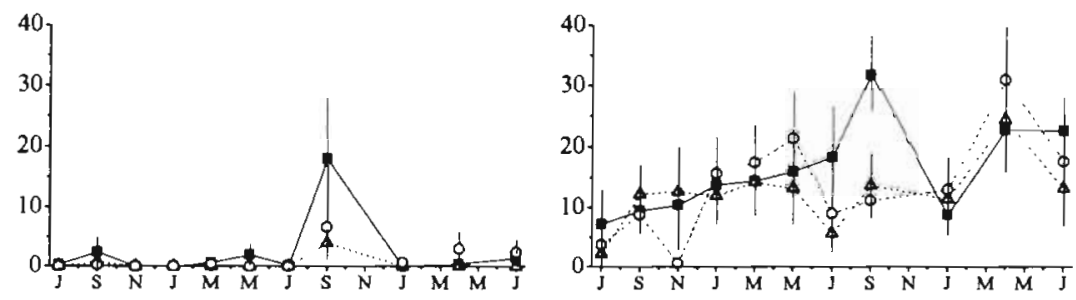

B Encrusting algae
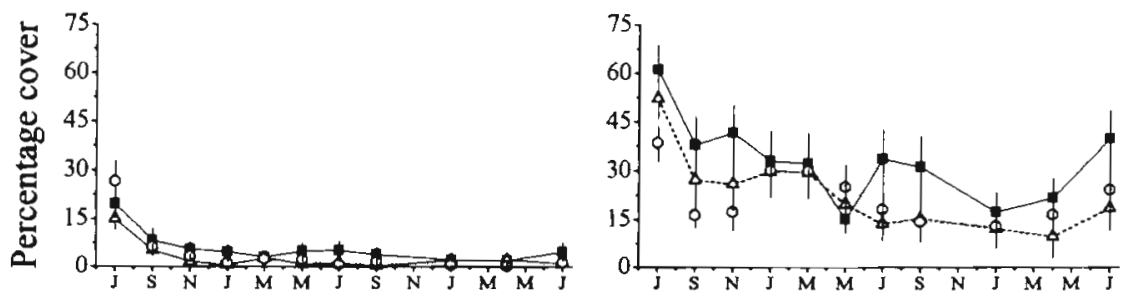

C Rivularia spp.
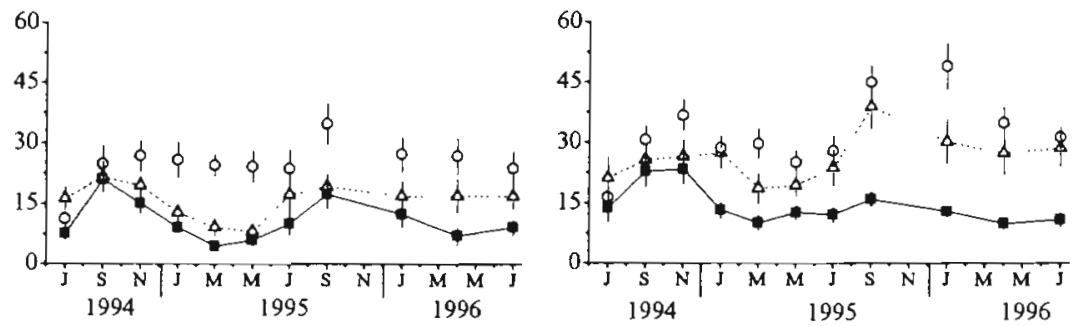

occupying areas where they did not occur before, as in the case of Rissoella, or change their local abundance as in the case of encrusting algae, Rivularia, limpets and the recruits of Chthamalus. Clearing areas of substratum had similar effects at different heights on the shore. With the exception of Rivularia, there were no significant Disturbance $\times$ Margin or Rissoella $\times$ Margin interactions in the analyses. Thus, the model that preemption of the substratum maintained differences among patches low, but not high on the shore, was not

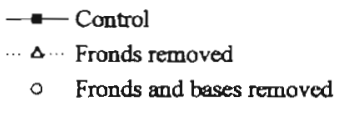

Fig. 5. Effects of removing Rissoella at its upper and lower margins of distribution on (A) Chthamalus and (B) Patella. Data are mean percentage covers for barnacles and mean densities for limpets ( $\pm \mathrm{SE}, \mathrm{n}=12$ ) from 3 replicate plots pooled across 4 replicate sites at margin

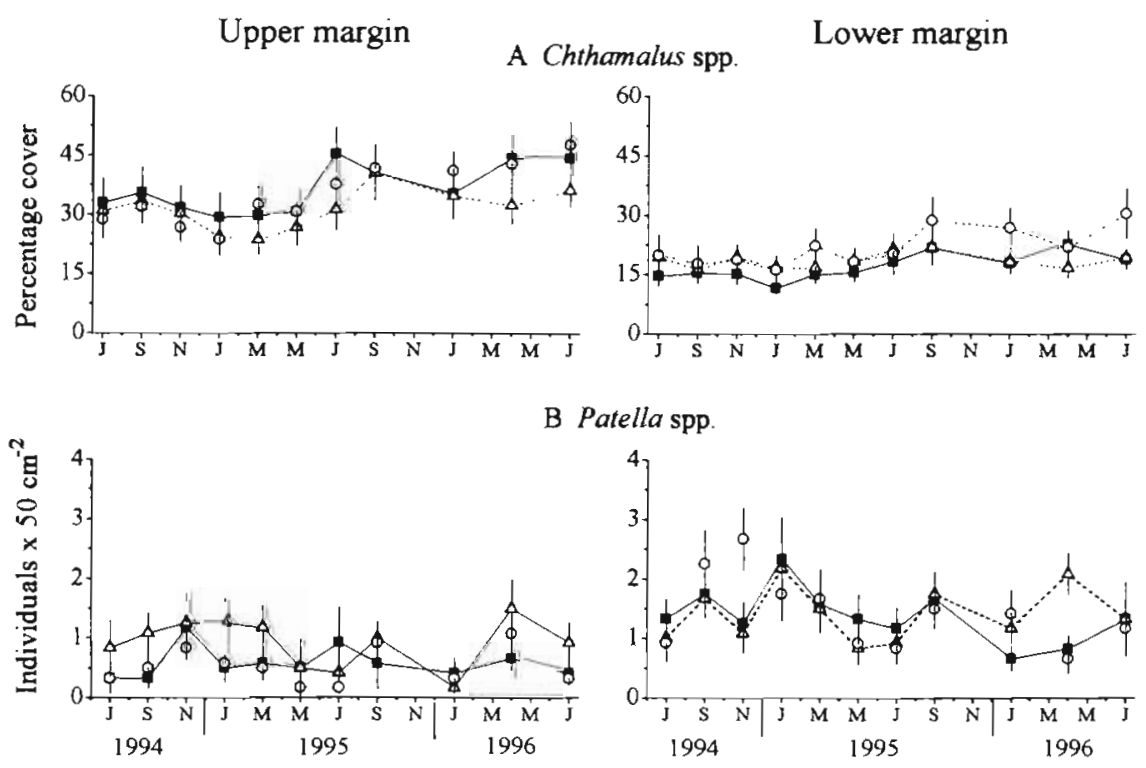


Table 2. Analysis of variance on mean percentage covers of filamentous algae encrusting algae and Rivularia at the upper and lower margins of distribution of Rissoella. $p<0.05, \cdots p<0.01, \cdots p<0.001$

\begin{tabular}{|c|c|c|c|c|c|c|c|}
\hline \multirow[t]{2}{*}{$\begin{array}{l}\text { Source of } \\
\text { variation }\end{array}$} & \multirow[t]{2}{*}{ df } & \multicolumn{2}{|c|}{$\begin{array}{c}\text { Filamentous } \\
\text { algae }\end{array}$} & \multicolumn{2}{|c|}{ Encrusting algae } & \multicolumn{2}{|c|}{$\begin{array}{l}\text { Rivularia } \\
\text { spp. }\end{array}$} \\
\hline & & MS & $F$ & MS & $F$ & $\mathrm{MS}$ & $F$ \\
\hline Rissoella: Ri & 2 & 4.13 & 1.69 & 392.85 & 3.19 & 2555.14 & $19.95 \cdots$ \\
\hline Margin: Ma & 1 & 90.24 & $19.77^{\circ}$ & 6199.99 & $11.90^{\circ}$ & 1113.92 & 5.36 \\
\hline $\mathrm{Ri} \times \mathrm{Ma}$ & 2 & 0.44 & 0.18 & 115.84 & 0.94 & 211.46 & 1.65 \\
\hline Site(Ma) & 6 & 4.57 & 1.83 & 520.83 & $4.15^{\cdots}$ & 207.80 & 1.75 \\
\hline $\mathrm{Ri} \times \operatorname{Site}(\mathrm{Ma})$ & 12 & 2.45 & 0.98 & 123.06 & 0.98 & 128.10 & 1.08 \\
\hline Residual & 48 & 2.50 & & 125.51 & 0.10 & 118.91 & \\
\hline \multicolumn{2}{|c|}{$\begin{array}{l}\text { Cochran's test } \\
\text { Transformation: }\end{array}$} & \multicolumn{2}{|c|}{$\begin{array}{c}C=0.22, p>0.05 \\
\text { Square root }(x+1)\end{array}$} & \multicolumn{2}{|c|}{$\begin{array}{c}C=0.22, p>0.05 \\
\operatorname{Arcsin}(\%)\end{array}$} & \multicolumn{2}{|c|}{$\begin{array}{c}C=0.18, \mathrm{p}>0.05 \\
\text { None }\end{array}$} \\
\hline
\end{tabular}

Table 3. Analysis of variance on mean abundances of animals at the upper and lower margins of distribution of Rissoella. $p<<0.05, \cdots p<0.01, \cdots p<0.001$

\begin{tabular}{|c|c|c|c|c|c|c|c|}
\hline \multirow[t]{2}{*}{$\begin{array}{l}\text { Source of } \\
\text { variation }\end{array}$} & \multirow[t]{2}{*}{$\mathrm{df}$} & \multicolumn{2}{|c|}{$\begin{array}{c}\text { Chthamalus } \\
\text { spp. }\end{array}$} & \multicolumn{2}{|c|}{ Limpets } & \multicolumn{2}{|c|}{$\begin{array}{c}\text { Recruits of } \\
\text { Chthamalus spp. }\end{array}$} \\
\hline & & MS & $F$ & MS & $F$ & MS & $F$ \\
\hline Rissoella: $\mathrm{Ri}$ & 2 & 267.25 & 1.91 & 0.158 & 1.92 & 3519.04 & $14.55^{\circ}$ \\
\hline Margin: Ma & 1 & 5842.81 & 5.28 & 1.734 & 3.54 & 53.39 & 0.06 \\
\hline $\mathrm{Ri} \times \mathrm{Ma}$ & 2 & 77.81 & 0.56 & 0.021 & 0.25 & 48.26 & 0.20 \\
\hline Site(Ma) & 6 & 1107.50 & $5.73 \cdots$ & 0.450 & $3.90^{\circ}$ & 830.87 & 1.62 \\
\hline Ri $\times$ Site $(\mathrm{Ma})$ & 12 & 139.78 & 0.72 & 0.082 & 0.66 & 241.86 & 0.47 \\
\hline Residual & 48 & 193.19 & & 0.125 & & 512.67 & \\
\hline \multicolumn{2}{|l|}{ Cochran's test } & \multicolumn{2}{|c|}{$C=0.19, p>0.05$} & \multicolumn{2}{|c|}{$C=0.18, p>0.05$} & \multicolumn{2}{|c|}{$C=0.17, \mathrm{p}>0.05$} \\
\hline
\end{tabular}

on the shore. The lack of a significant Disturbance $\times$ Margin interaction suggested that physical factors associated with aerial exposure were not the proximate factors limiting the vertical extension of Rissoella. These biological processes were, however, variable from place to place, as indicated by the significant Disturbance $\times$ Site interaction. The response of Rissoella to the experimental clearings was negligible in some sites and large in others. This suggested that the effects of removing neighbours from the substratum could depend on physical and/or biological processes that changed along the shore, rather than along the vertical gradient. Variability from place to place could reflect slight differences in the aspect of the substratum, in exposure to waves and in solar radiation. Alternatively, the variable response of Rissoella might be due to variability in patterns of recruitment of this alga, a process that is under the influence of a combination of physical and biological factors on its own (e.g. Menge et al. 1993). Limpets, although potentially important for other algae, have no relevant direct effects on Rissoella (Benedetti-Cecchi \& Cinelli 1993, 1997, Benedetti-Cecchi unpubl. data).

supported by the experimental results. Rather, the results indicated that pre-emption of the substratum operated independently of physical and/or other untested biological processes (e.g. grazing) that might have affected the vertical patterns of distribution. In contrast, level on the shore per se, and the differences among sites, accounted for most of the variation in patterns of abundance of algae and invertebrates.

Biological processes were clearly important in setting the upper and lower limits of distribution of Rissoella and in maintaining spatial heterogeneity at different levels
Apparently, Rissoella was more prone to colonize new patches of substratum as a crust during the summer months, although the differences between dates disappeared with time. This suggested that vegetative propagation was important in this alga, since the reproductive structures develop on the erect blades (Feldmann 1937). However, these results were confounded by the lack of replicated dates within seasons and further research is needed to clarify these patterns.

There was also a trend for Rissoella to be more abundant in total removal than half removal plots, sug-
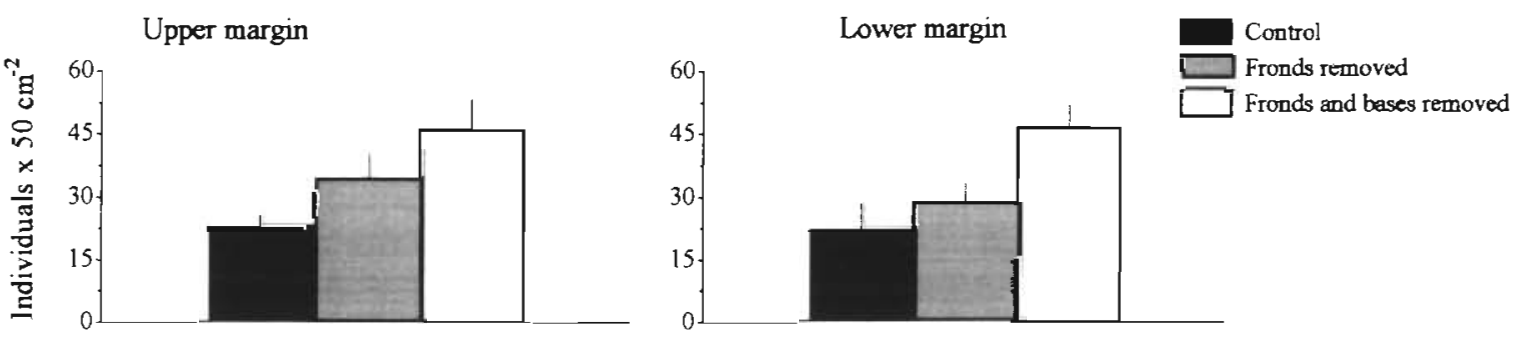

Fig. 6. Chthamalus sp. Effects of removing Rissoella at its upper and lower margins of distribution on recruitment of Chthamalus in July 1995. Data are mean numbers of recruits $( \pm S E, n=12$ ) from 3 replicate plots pooled across 4 replicate sites at each margin 
gesting that pre-emption of the substratum was more effective in small clearings. As a possible explanation, the turf-forming algae might have re-invaded the experimental plots through vegetative propagation from the margins, so that the small clearings remained suitable for colonization by Rissoella only for short periods (e.g. Sousa 1985). If this was the case, then the response of Rissoella to the provision of cleared space can be enhanced by using plots of a larger size than those employed in the present experiment. This prediction can be tested in future experiments.

The removal of turf-forming/encrusting algae increased the abundance of Rivularia at low levels on the shore. In contrast, the removal of barnacles had no effects at higher levels. These results supported the model that pre-emption of the substratum and physical factors were key processes in influencing the spatial distribution of cyanobacteria at low and high levels on the shore, respectively. However, these patterns were not consistent from date to date: significant effects of the turf-forming/encrusting algae were detected only in the experiment initiated in winter. This variability probably reflected short-term temporal changes in the abundance of Rivularia, rather than true seasonal effects. In a previous study on the same shore (Menconi et al. 1999), we found that cyanobacteria fluctuated considerably in abundance at small spatial and temporal scales, probably as a consequence of variable patterns of recruitment, growth and mortality of these organisms.

That limpets require areas of cleared substratum for adhesion and grazing is well established (e.g. Underwood \& Jernakoff 1981), so the fact that removing sessile organisms increased the local density of Patella may not be very surprising. However, it is interesting to note that the removal of barnacles was done in proximity to the upper limit of distribution of limpets on the shore, and in particular of Patella rustica (see also Menconi et al. 1999), and that the effect of this manipulation was comparable to that observed after the removal of turf-forming/encrusting algae lower down. In addition, the response of limpets to these treatments was consistent in time. These outcomes did not support the model that the upper limits of distribution of mobile organisms living at high levels on the shore, but at the lower border of an unexploited resource, are set by physical factors (Wolcott 1973). Patches of microscopic algae and filamentous macroalgae often develop in areas of the shore above limpets and occupied by barnacles (Benedetti-Cecchi pers. obs). Although the availability of these resources is often unpredictable, the unsuitable habitat provided by barnacles appeared to be the main factor preventing limpets from exploiting these patches, rather than the effects of physical stress (Benedetti-Cecchi unpubl. data).
The effects of removing Rissoella differed to some extent from those discussed above, but still supported the conclusion that pre-emption of the substratum by a dominant species had similar effects at different tidal levels in this system. In general, the effects of removing the whole plant of Rissoella were larger than those resulting from the removal of the erect fronds alone, indicating that the encrusting base of the alga played a role in preventing the establishment of other organisms. The percentage cover of Rivularia increased significantly when Rissoella was completely removed from the substratum, both at the upper and lower margins of distribution of this alga. In contrast to what was observed after clearing plots of barnacles or turf-forming/encrusting algae, the removal of Rissoella had no effects on limpets. Also the filamentous algae were unaffected by this treatment. The lack of a significant effect of Rissoella on limpets was in agreement with the results of a previous analysis on the spatial and temporal patterns of distribution of these grazers (Menconi et al. 1999). This analysis did not identify any significant correlation between the density of limpets and the presence of Rissoella on the shore

In contrast, the removal of Rissoella significantly decreased the abundance of the encrusting algae, as indicated by the SNK tests. Possibly, the fronds of Rissoella reduced the effects of solar radiation and desiccation, providing better physical conditions for the encrusting algae. Interestingly, the effects of Rissoella were similar at the 2 margins, although the encrusting plants were significantly more abundant in correspondence to the lower one. This indicated that physical factors probably played a major role in limiting the distribution of these algae high on the shore, but that these factors operated independently of the presence of Rissoella. Overall, these patterns contributed to the view that positive interactions can be important determinants of the structure of assemblages in stressful habitats (Bertness \& Callaway 1994). In an experimental analysis on factors influencing the vertical distribution of intertidal species on rocky shores in New England, Bertness \& Leonard (1997) concluded that positive interactions were as important in maintaining the upper limits of distribution of dominant species as negative interactions were in setting the lower limits. As argued by Bertness \& Leonard (1997), among others, positive interactions should be explicitly included as causal processes into models that seek to predict and explain the patterns of distribution of natural populations in stressful habitats.

In contrast to the experimental clearing of adult barnacles and turf-forming/encrusting algae, the removal of Rissoella significantly increased the number of recruits of Chthamalus, although it did not affect the percentage cover of these animals. These patterns sug- 
gested that Rissoella exerted both positive and negative effects on barnacles. Possibly, although limiting the initial establishment of cyprids, this alga increased the survival of those animals that recruited beneath its fronds (see also Hawkins 1983). This would explain why the increased recruitment in cleared plots did not translate into a larger percentage cover of barnacles in the absence rather than in the presence of Rissoella. While the negative effects of Rissoella might reflect a reduced chance for larvae of barnacles to find a suitable substratum for settlement, the mechanisms underlying the positive effects of this alga were more difficult to identify. The removal of Rissoella might have increased physical stress, enhancing the mortality of recruits of Chthamalus. As an alternative explanation, the increased mortality of barnacles could reflect a density-dependent mechanism of regulation of these populations which was unrelated to the presence of Rissoella (e.g. Connell 1985). Increased predation in the absence of Rissoella might also account for these differences, although predators of barnacles were uncommon in the study system. Clearly, more research is needed to distinguish among these alternatives.

One of the main assumptions in many studies about spatial heterogeneity is that ecological systems are organised as mosaics of patches that are separated by distinct boundaries (Wiens et al. 1985). Thus, understanding ecological heterogeneity requires knowledge of the processes that maintain discontinuities among patches. One might argue that the relevance of this approach is proportional to the discreteness of the boundaries between adjacent patches. This, in turn, depends on how a patch is defined. In the present study a patch was identified on the basis of the dominant organism/s that occupied a particular area of the substratum. The boundaries that could be unambiguously identified using this definition were only those provided by the upper and lower margins of distribution of Rissoella (see also Menconi et al. 1999). Borrowing the terminology from landscape ecology, these boundaries were 'permeable' to most of the animals and plants that dominated above and below Rissoella. The spatial distribution of these organisms was influenced by Rissoella, but their limits of distribution did not coincide with those of this plant.

These patterns suggested that patchy habitats such as rocky shores, may be described more realistically as environments where only some conspicuous species form patches with distinct boundaries, while changes in abundance from place to place occur gradually and independently for most of the other organisms. This was the case for the system considered here (see also Menconi et al. 1999). The large differences among sites observed in the present study also indicated that confining the analysis of spatial heterogeneity at loca- tions where apparent or real boundaries occur is limiting. In addition to focusing on factors maintaining boundaries between patches, the analysis of spatial patterns should also consider models of the distribution of animals and plants that explicitly embrace a hierarchy of spatial scales (Kotliar \& Wiens 1990, Wu \& Loucks 1995, Underwood \& Chapman 1996). This would increase our understanding of the processes involved in generating spatial differences in the abundance of populations on rocky shores.

Acknowledgements. We sincerely thank R. Coleman and S. J. Hawkins for their comments on an earlier draft of this manuscript. This research was funded by a MURST $60 \%$ project and by the EU under MAST programme contract MAS3CT95-0012 (EUROROCK).

\section{LITERATURE CITED}

Bender DJ, Contreras TA, Fahrig L (1998) Habitat loss and population decline: a meta-analysis of the patch size effect. Ecology 79:517-533

Benedetti-Cecchi L, Cinelli F (1993) Early patterns of algal succession in a midlittoral community of the Mediterranean sea: a multifactorial experiment. J Exp Mar Biol Ecol 169:15-31

Benedetti-Cecchi L, Cinelli F (1994) Recovery of patches in an assemblage of geniculate coralline algae: variability at different successional stages. Mar Ecol Prog Ser 110:9-18

Benedetti-Cecchi L, Cinelli F (1997) Confounding in field experiments: direct and indirect artifacts due to the manipulation of limpets and macroalgae. J Exp Mar Biol Ecol 209:171-184

Bertness MD, Callaway R (1994) Positive interactions in communities: a post cold war perspective. TREE 9:191-193

Bertness MD, Leonard GH (1997) The role of positive interactions in communities: lessons from intertidal habitats Ecology 78:1976-1989

Chapman MG, Underwood AJ (1992) Foraging behaviour of marine benthic grazers. In: John DM, Hawkins SJ, Price $\mathrm{JH}$ (eds) Plant-animal interactions in the marine benthos. Clarendon Press, Oxford, p 289-317

Connell JH (1961) The influence of interspecific competition and other factors on the distribution of the barnacle Chthamalus stellatus. Ecology 42:710-723

Connell JH (1972) Community interactions on marine rocky intertidal shores. Annu Rev Ecol Syst 3:169-192

Connell JH (1985) The consequences of variation in initial settlement vs. post-settlement mortality in rocky intertidal communities. J Exp Mar Biol Ecol 93:11-45

Cubit JD (1984) Herbivory and the seasonal abundance of algae on a high intertidal rocky shore. Ecology 65: $1904-1917$

Danielson BJ (1991) Communities in a landscape: the influence of habitat heterogeneity on the interactions between species. Am Nat 138:1105-1120

Dayton PK (1992) Community landscape: scale and stability in hard-bottom marine communities. In: Giller PS, Hildrew AG, Raffaelli DG (eds) Aquatic ecology. Scale, patterns and process. Blackwell, Oxford, p 289-332

Diffendorfer JE, Gaines MS, Holt RD (1995) Habitat fragmentation and movements of three mammals (Sigmodon, Microtus and Peromyscus). Ecology 76:827-839 
Feldmann J (1937) Recherches sur la végétation marine de la Mediterranée. La côte des Albères. Rev Algol 10:1-339

Gaines S, Brown S, Roughgarden J (1985) Spatial variation in larval concentrations as a cause in spatial variation in settlement for the barnacle Balanus glandula. Oecologia 67 : $267-272$

Graham MH (1997) Factors determining the upper limit of giant kelp, Macrocystis pyrifera Agardh, along the Monterey Peninsula, central California, USA. J Exp Mar Biol Ecol 218:127-149

Grosberg RK (1982) Intertidal zonation of barnacles: the influence of planktonic zonation of larvae on vertical distribution of aduits. Ecology 63:894-899

Hawkins SJ (1983) Interaction of Patella and macroalgae with settling Semibalanus balanoides (L.). J Exp Mar Biol Ecol $71: 55-72$

Hawkins SJ, Hartnoll RG (1985) Factors determining the upper limits of intertidal canopy forming algae. Mar Ecol Prog Ser 20:265-271

Kotliar NB, Wiens JA (1990) Multiple scales of patchiness and patch structure: a hierarchical framework for the study of heterogeneity. Oikos 59:253-260

Lewis JR (1964) The ecology of rocky shores. English University Press, London

Lubchenco J (1980) Algal zonation in the New England rocky intertidal community: an experimental analysis. Ecology 61:333-344

Lubchenco J (1982) Effects of grazers and algal competitors on fucoid colonization in pools. J Phycol 18:544-550

Menconi M. Benedetti-Cecchi L, Cinelli F (1999) Spatial and temporal variability in the distribution of algae and invertebrates on rocky shores in the northwest Mediterranean. J Exp Mar Biol Ecol 233:1-23

Menge BA, Sutherland JP (1987) Community regulation: variation in disturbance, competition, and predation in relation to gradients of environmental stress and recruitment. Am Nat 130:730-757

Menge BA, Farrell TM, Olson AM, van Tamelen P, Turner T (1993) Algal recruitment and the maintenance of a plant mosaic in the low intertidal region on the Oregon coast. J Exp Mar Biol Ecol 170:91-116

Moreno CA, Jaramillo E (1983) The role of grazers in the zonation of intertidal macroalgae of the Chilean coast. Oikos 41:73-76

Norton TA (1985) The zonation of seaweeds on rocky shores. In: Moore PG, Seed R (eds) The ecology of rocky coasts. Hodder and Stoughton, London, p $7-21$

Paine RT (1974) Intertidal community structure: experimental studies on the relationship between a dominant competitor and its principal predator. Oecologia 15:93-120

Pickett STA, White PS (1985) The ecology of natural disturbance and patch dynamics. Academic Press, Orlando.

Santelices B, Ojeda FP (1984) Population dynamics of coastal forests of Macrocystis pyrifera in Puerto Toro, Isla

Editorial responsibility: Otto Kinne (Editor),

Oldendorf/Luhe, Germany
Navarino, Southern Chile. Mar Ecol Prog Ser 14:175-183 Schonbeck MW, Norton TA (1978) Factors controlling the upper limits of fucoid algae on the shore. J Exp Mar Biol Ecol 31:303-313

Schonbeck MW, Norton TA (1980) Factors controlling the lower limits of fucoid algae on the shore. J Exp Mar Biol Ecol 43:131-150

Sousa WP (1985) Disturbance and patch dynamics on rocky intertidal shores. In: Pickett STA, White PS (eds) The ecology of natural disturbance and patch dynamics. Academic Press, Orlando, p 101-124

Sousa WP, Schroeter SC, Gaines SD (1981) Latitudinal variation in intertidal algal community structure: the influence of grazing and vegetative propagation. Oecologia 48 . 297-307

Southward A.J (1958) The zonation of plants and animals on rocky sea shores. Biol Rev $33: 137-177$

Stamps JA, Buechner M, Krishnan VV (1987) The effects of edge permeability and habitat geometry on emigration from patches of habitat. Am Nat 129:533-552

Stephenson TA, Stephenson A (1949) The universal feature of zonation between tide-marks on rocky coasts. $J$ Ecol 37 289-305

Turner MG, Arthaud GJ, Engstrom RT, Hijl SJ, Liu J, Loeb S McKelvey K (1995) Usefulness of spatially explicit population models in land management. Ecol Appl 5:12-16

Underwood AJ (1980) The effects of grazing by gastropods and physical factors on the upper limits of distribution of intertidal algae. Oecologia 46:201-213

Underwood AJ (1985) Physical factors and biological interactions: the necessity and nature of ecological experiments. In: Moore PG, Seed R (eds) The ecology of rocky coasts. Hodder \& Stoughton, London, p 372-390

Underwood AJ (1997) Experiments in ecology: their logical design and interpretation using analysis of variance. Cambridge University Press, Cambridge

Underwood AJ, Jernakoff $P$ (1981) Effects of interactions between algae and grazing gastropods on the structure of a low shore intertidal algal community. Oecologia 48 $221-223$

Underwood AJ, Chapman MG (1996) Scales of spatial patterns of distribution of intertidal invertebrates. Oecologia 107:212-224

Wiens JA, Crawford CS, Gosz JR (1985) Boundary dynamics: a conceptual framework for studying landscape ecosystems. Oikos 45:421-427

Wiens JA, Stenseth NC, Van Horne B, Ims RA (1993) Ecological mechanisms and landscape ecology. Oikos 66:369-380

Wolcott TG (1973) Physiological ecology and intertidal zonation in limpets (Acmea): a critical look at 'limiting factors' Biol Bull Mar Biol Lab Woods Hole 145:389-422

Wu J, Loucks OL. (1995) From balance of nature to hierarchical patch dynamics: a paradigm shift in ecology. $Q$ Rev Biol 70:439-466

Submitted: October 7, 1998; Accepted: December 23, 1998 Proofs received from author(s): April 30, 1999 